\title{
Evaluation of models for dermal exposure assessment in farming systems in developing countries
}

\author{
Camilo Lesmes Fabian ${ }^{1 *}$, Silvia Teubl ${ }^{2}$ and Claudia R. Binder ${ }^{3}$ \\ *Correspondence: lesmesandres@hotmail.com \\ ${ }^{1}$ Research Group in Environmental, Civil Engineering and Basic Sciences, Universidad Santo Tomas Seccional Tunja, Colombia. Sede \\ Campus: Av. Universitaria Cll. 48 No. 1-235 Este. Tunja, Boyacá, Colombia. \\ ${ }^{2}$ Karl Franzens University of Graz, Merangasse 18, 8010, Graz, Austria. \\ ${ }^{3}$ Human-Environment Relations, Department of Geography, Ludwig Maximilian University of Munich, Luisenstrasse 37, D-80333, \\ Munich, Germany.
}

\begin{abstract}
Dermal Exposure Assessment is a crucial aspect within the risk assessment of pesticide use as it may lead to the development and improvement of measures to reduce the health risk of pesticides users. Even though, tools for dermal exposure assessment are available, their implementation in developing countries is problematic as they are designed under working conditions in industrialized countries and most of them are not specifically focused on processes like pesticide management. This paper evaluates dermal exposure models finding out the most appropriate ones to assess dermal exposure of pesticide use in farming systems in developing countries. Seven models (i.e. COSHH, DERM, DREAM, EASE, PHED, RISKOFDERM and STOFFENMANAGER) were evaluated according to a multi-criteria analysis and four models (i.e. DERM, DREAM, PHED and RISKOFDERM) were selected for the assessment of dermal exposure in the case study of potato farming systems in Vereda La Hoya in the highlands in Colombia. The model estimations were compared with dermal exposure measurements made in the study area. The results show that the four models provide different dermal exposure estimations which are not comparable. Because of the simplicity of the algorithms and the specificity of the determinants, the models DERM and DREAM were found to be the most appropriate ones. In addition, it was found that model outcomes would be more accurate in the assessment if determinants like climate conditions, cleaning of the equipment, task duration, personal protective equipment and hygiene habits are included in the models. When comparing the final model assessment of dermal exposure in the study area, DREAM was found as the model that assesses more appropriately dermal exposure because of the qualitative assessment and the type of determinants included in the model.
\end{abstract}

Keywords: Dermal exposure, models, developing countries, potato

\section{Introduction}

The agricultural sector is under pressure to increase crop productivity in order to maintain the food security for an increasingly growing population [10]. FAO has reported that 868 million people continue to suffer from undernourishment and the negative health consequences of micronutrient deficiencies continue to affect around 2 billion people [10]. Pests affect agricultural productivity by causing losses in the agricultural output, storage and the distribution of products. Worldwide approximately 9,000 species of insects and mites, 50,000 species of plant pathogens, and 8,000 species of weeds damage crops [40]. In different crops worldwide pests can cause losses of 14\% by insects, $13 \%$ by plant pathogens and $13 \%$ by weeds [26] but there is an overall decline in crop losses when pesticides are used. However, even though pesticides play an important role in plant protection, in many cases, overuse or inappropriate use compromise the health of pesticide users, agricultural workers, and bystanders [9].

The occupational hygiene field has turned the attention to investigate the exposure in the agricultural workplace in order to improve the pesticide management and to reduce the health risk [11]. In developing countries this is of special interest because pesticide management activities face weak safety standards $[2,12,13,17]$. Studies in potato farming systems in Vereda La Hoya in Colombia [12,13,15,18,21,30]. Mojanda, Ecuador [31]; and El Angel, Ecuador [27] have shown that pesticide management in these countries has no particular knowledge foundation and is performed by trial and error, finding out what works out in practice. Furthermore, farmers do not wear adequate personal protective equipment, apply pesticides which are banned in industrialized countries and modify the standard discharge of nozzles to reduce the application time [21]. Because these issues increase the health risk, a risk assessment of pesticide use in these areas is required in order to determine the risk level faced by people.

Human exposure to pesticides occurs via three main pathways: inhalation, ingestion and dermal contact $[\mathbf{2 8 , 2 9 ]}$. Of these three, dermal exposure is the most complex one and there is still no consensus about the most appropriate way to evaluate it $[\mathbf{2 8 , 2 9 ]}$. There are different models available that might be applied to assess dermal exposure to pesticide use in developing countries like EASE [5]. EUROPOEM [36], PHED [8], RISKOFDERM [37], COSHH [16], STOFENMANAGER [23], DREAM [35], DERM [3] and the approaches proposed by the U.S.EPA [34]; 
however, there are still uncertainties about the adequacy of these models when they are applied in developing countries as most of them have been developed in industrialized countries, at occupational situations in industrialized processes in Europe and USA, and do not consider agricultural processes like pesticide management. In the case of the model DERM, even though it has been developed under conditions relevant for developing countries, its methodology has been criticized and the model itself has not been validated.

The goal of this paper is to evaluate the available models for dermal exposure assessment in order to find out the most adequate one to estimate the dermal exposure in farming systems in developing countries. To reach this goal the following research questions will be addressed:

a. Which of the existing models for dermal exposure are feasible to be applied in case studies in farming systems in developing countries?

b. What are the most relevant parameters to be taken into account to increase the confidence and accuracy level of the estimations?

c. When comparing the model outcomes with the dermal exposure measurements in the study area, which models assess dermal exposure more accurately?

\section{Methodology}

After a literature review seven available models were considered for the analysis: COSHH [16], DERM [3], DREAM [35], EASE [5], PHED [8], RISKOFDERM [37] and STOFFENMANAGER [23]. These models were selected because of their availability, clear description of the algorithms, and their potential applicability in the assessment of pesticide use. They were analyzed according to the following group of criteria (Table 1):

a. General characteristics of the model: year of development, country of origin, model goal, conceptual basis.

b. Usability of the Model: target group, availability, guidance, knowledge/equipment required, reliability, data required as input, type of outcome.

c. Characteristics of the assessment: type of exposure, type of substance, physical state of evaluated the substance, dermal exposure pathway, dermal exposure descriptor, evaluated body part.

\section{Models for dermal exposure assessment}

COSHH (Control of Substances Hazardous to Health Regulations):

Table 1. Categories and related criteria considered for the analysis and comparison of dermal exposure assessment models.

\begin{tabular}{|c|c|c|}
\hline Categories & Related Criteria & Categories \\
\hline \multirow[t]{2}{*}{ General Characteristics } & Year of development & -- \\
\hline & Country of origin & -- \\
\hline \multirow[t]{5}{*}{ Usability } & Target group & Farms, SME`s, Industry \\
\hline & Guidance & $\begin{array}{l}\text { No Guidance, Website showing only the results, Publication showing all the } \\
\text { calculations }\end{array}$ \\
\hline & Knowledge required & $\begin{array}{l}\text { No specific knowledge required, Basic knowledge about human exposure } \\
\text { assessment required and informatics, Advance knowledge required about } \\
\text { human exposure assessment and programming }\end{array}$ \\
\hline & Reliability & $\begin{array}{l}\text { No reliable, Partly reliable because it is not completely validated, Reliable } \\
\text { because it has been validated }\end{array}$ \\
\hline & Outcome & Qualitative, Semi-quantitative, Quantitative \\
\hline \multirow[t]{3}{*}{ Assessment } & Evaluated substances & $\begin{array}{l}\text { Other substances different from pesticides, Pesticides only, Pesticides and } \\
\text { other chemical }\end{array}$ \\
\hline & Dermal exposure descriptor & Potential, Actual and Potential, Actual \\
\hline & Evaluated body parts & $\begin{array}{l}\text { No body parts are evaluated, Some of the body parts are evaluated, All the } \\
\text { body parts are evaluated }\end{array}$ \\
\hline
\end{tabular}

The exposure assessment model COSHH was developed in the United Kingdom (UK) by the Health and Safety Executive (HSE) and has been used since 2002. Originally, the model is targeted on large companies and safety professionals who have the equipment and the knowledge to apply the model and interpret the law [16]. Later on, a new version of the model was developed, namely the model COSHH Essential (COSHH-E). This is an improved version that provides assistance to small and medium-sized enterprises (SMEs) that have limited available resources. The goal of this model is to provide easy-to-understand and easy-to-use assistance to SMEs, and to give advice on how to control the chemical risks [16].

DERM (Dermal Exposure Ranking Method): It was developed in a project called "Assessment of dermal pesticide exposure and pesticide-related skin lesions: implication for intervention". The fieldwork of the study was conducted at the Universidad Nacional Autónoma de Nicaragua (UNAN-León) and first published in 2008 [3]. The goal of DERM is to develop a low-cost, easy-to-use method to assess dermal exposure to pesticides in developing countries. The model concentrates 
on assessing dermal exposure in terms of the potential and actual exposure. The outcome can answer questions like which determinants causes the highest exposure among subsistence farmers, and/or which farmers are the most exposed while working on the field [3].

DREAM (Dermal Exposure Assessment Method): The model DREAM was developed in the Netherlands in 2003 [35]. The goal of the model was to create a method that can assess and evaluate occupational dermal exposure to chemical agents in a generic way. The model can be used in occupational hygiene and epidemiology for any given situation. It can be used for initial assessment of dermal exposure levels of liquids and solids, as a framework for measurement strategies (i.e., who, what and where to measure), or as a basis for control measures. It gives insight into the distribution of dermal exposure over the body and indicates in which routes the exposure takes place. The outcome is a numerical estimate indicating the amount of dermal exposure that workers encounter while performing a certain task. The estimate is divided into seven intervals ranging from 0 to 1,000 (no exposure to extremely high exposure) [35].

EASE (Estimation and Assessment of Substance Exposure): This model was developed in the early 1990s by the UK's Health and Safety Executive $[5,6]$. The model can assess inhalation and dermal exposure. For inhalation exposures, the model predicts a range of expected exposure levels for a given set of circumstances. For dermal exposures, the model predicts the potential exposure for hands and forearms (no other body parts are considered), expressed as a mass per unit area of exposed skin per day $\left(\mathrm{mg} / \mathrm{cm}^{2} /\right.$ day). The exposure ranges can take five different values, from very low up to $5-15 \mathrm{mg} / \mathrm{cm}^{2} /$ day. The model EASE was one of the first models to assess dermal exposure. Originally, this model was used as a screening tool for regulatory risk assessment for new chemicals. Nowadays, EASE is more a risk assessment tool to estimate exposure of new or existing substances in a simplified way $[5,6]$.

PHED (Pesticide Handlers Exposure Database): The first version of this model was published in $1992[8,34]$. The database of the model was developed by a task force, consisting of representatives from the Health Canada Pest Management Regulatory Agency (PMRA), the United States Environmental Protection Agency (EPA), the American Crop Protection Association (ACPA), and the software by an environmental consulting firm in Springfield, Virginia. The model was used by all major regulatory agencies in USA and worldwide by many other regulatory groups. Also, it was used by the pesticide industry to evaluate product safety issues $[8,19]$. Self-reported exposure information on pesticide from questionnaires, as well as pesticide monitoring data from the literature, were used to estimate the levels of exposure to pesticides. The database consists of information collected from about 100 studies submitted primarily by companies that wish to register a specific pesticide and it contains data for over 1,700 monitored exposure events [8].
RISKOFDERM (Risk Assessment of Occupational Dermal Exposure to Chemicals): RISKOFDERM was developed with the cooperation of 15 different institutes from 10 different European countries in 2003 [1,37]. The aim of the project was to develop a conceptual model for dermal risk assessment and management for regulatory purposes. It was created to be a simple-to-use toolkit for SMEs. The model can be used for comparison of the skin-related hazardous properties of chemical products, general recommendations for risk control, or assessment of health risk from skin exposure for a specific working task in the field [25].

STOFFENMANAGER: This model was developed in the Netherlands and has been used since 2003 [32]. Its goal is to assist SMEs in risk assessment and to prioritize and control risks of handling chemical products in their workplace. It was created to combine previous work published and requirements that are mandatory in the Netherlands for SMEs [23]. The model uses information from the COSHH model for its hazard banding and the publications by Cherrie (1996) [4] and Schneider (1999) [29] for the algorithm of the model. In addition, it uses information from the RISKOFDERM toolkit for the dermal exposure method and incorporates information from companies in the Netherlands gathered by several surveys. Sectors and companies were selected and the surveys were conducted by occupational hygienists. Also, information was used from research projects made by the Dutch government [32,33].

Selection of models for the evaluation in the study area The multi-criteria analysis was defined based on criteria of model characteristics such as availability, guidance, knowledge required, reliability, type of outcome, type of substance, target group, dermal exposure descriptor and dermal exposure pathway. After this evaluation, four models (i.e., DERM, DREAM, PHED, and RISKOFDERM) were selected to be applied in the case study of Vereda La Hoya in the highlands of Colombia. COSHH, EASE and STOFENMANAGER were not selected because they did not fulfill most of the criteria, as the results will show in the section 3.1 and (Figure 1). The data used as input to evaluate the models DERM, DREAM, PHED and RISKOFDERM was taken from a previous survey made in the study area with 197 smallholder potato growers in four communities [13] and previous studies about dermal exposure in the same study area $[15,21]$. The calculations and outcome of each model are provided in the supplementary information.

\section{Sensitivity analysis of de models}

The influence of each determinant in the model score for Vereda La Hoya was evaluated by a sensitivity analysis. Each determinant was evaluated for the models DERM, DREAM, PHED and RISKOFDERM according to the One-at a-Time sensitivity analysis methodology $[7,24]$. A series of scenarios were established for each model changing the input values to the score for one specific determinant according to the 


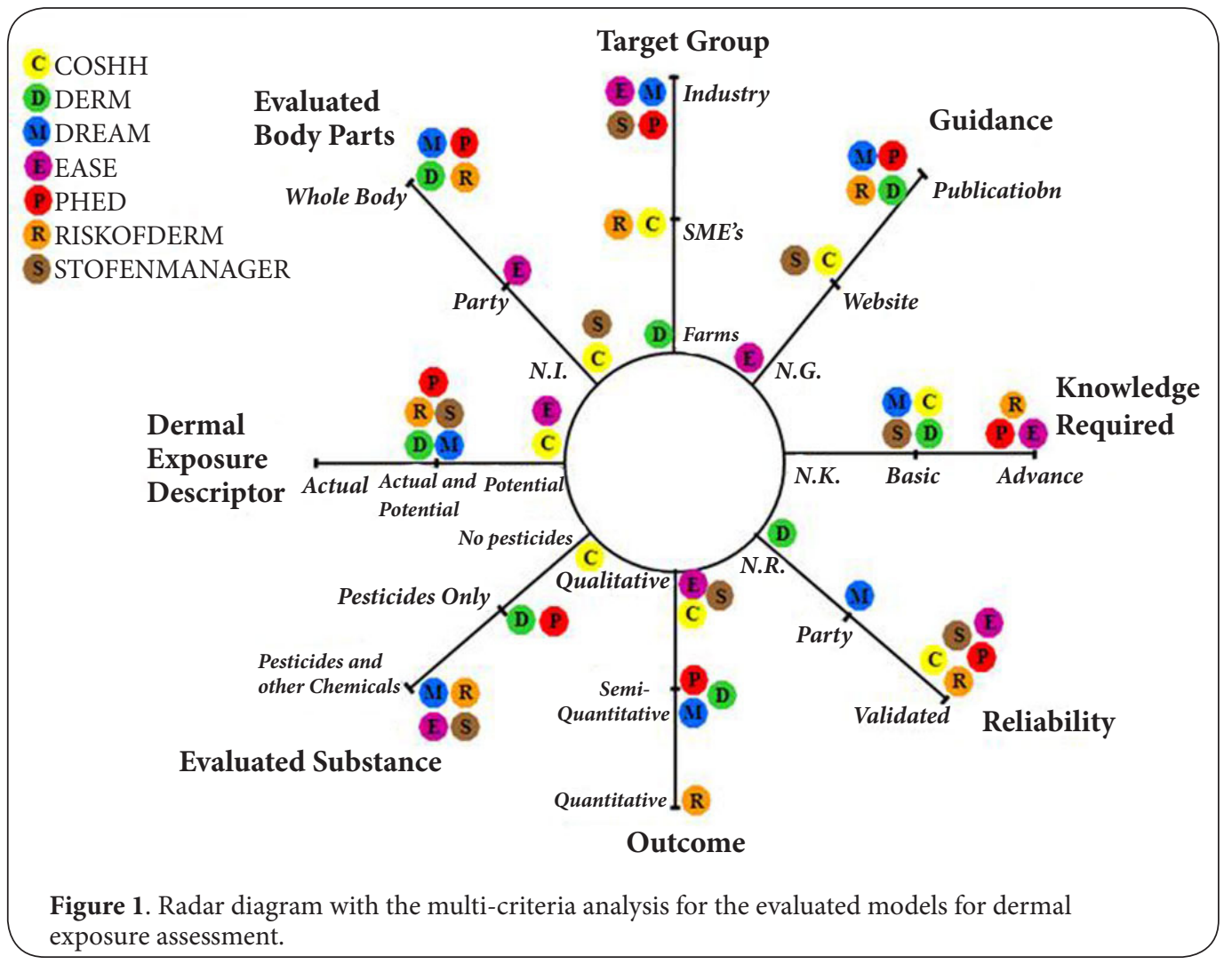

scores for the study area in Vereda La Hoya, leaving the rest of the determinants at the lowest input value. 16 determinants were evaluated in 16 scenarios for DERM, 14 for DREAM, 8 for PHED and 4 for RISKOFDERM, respectively. The difference in number of scenarios depended on the structure and number of determinants within each model.

\section{Description of the Study Area}

The study area selected was Vereda La Hoya which is a rural region that belongs to the city of Tunja in the highlands of Colombia. This region is devoted mainly to the cultivation of potato in production units of around 3 hectares. Potato crops in this region are vulnerable to three major pests: the soil-dwelling larvae of the Andean weevil (Premnotrypes vorax), the late blight fungus (Phytophthora infestans) and the Guatemalan potato moth (Tecia solanivora) [22]. The pesticide management to control these pests is performed along three main activities: the preparation of the pesticide, the application itself, and the cleaning of the spraying equipment $[18,21]$. During the whole pesticide management, farmers use work clothing consisting of trousers, short sleeve shirts and plastic boots. The pesticide management is performed along three main activities which are:

a. Pesticide preparation, which consists of opening the bottle containing the pure pesticide substance, mixing the solution of (different) pesticides and water, and loading the tank of the knapsack sprayer. Farmers in Vereda La
Hoya prepare the pesticides in a container of $100-\mathrm{L}$ capacity. The pesticide and the water (normally $80 \mathrm{~L}$ to obtain four applications of $20 \mathrm{~L}$ each) are mixed in this container with the aid of a wooden stick. During the mixing and the filling of the tank there are usually spills out of the container reaching different parts of the body including hands, arms, chest and legs.

b. Pesticide application, in which the knapsack sprayer is carried on the back and the pesticide application starts with the spraying process on the field. During this activity the farmers' body is exposed to the droplets emitted by the nozzles. In the study area, the spraying is performed with hand pressure sprayers with a 20-L capacity. Farmers use two types of nozzles for pesticide application which differ in the amount of pesticide discharged: a high-discharge (HD) nozzle $(1.88 \mathrm{~L} / \mathrm{min})$ used during the first crop phases (sowing and emergence) and a low-discharge (LD) nozzle $(1.26 \mathrm{~L} / \mathrm{min})$ used during the rest of the crop phases (growth, flowering and preharvest).

c. Cleaning, in which once the application is finished, farmers clean the sprayer and the container by pouring clean water on all the accessories in a procedure repeated three times. This procedure is included in the booklet "Good Agricultural Practices" [14], which farmers use as a reference for the pesticide management. During this activity, there are numerous spills from the equipment 
Lesmes Fabian et al. Journal of Environmental Engineering \& Ecological Science 2013, http://www.hoajonline.com/journals/pdf/2050-1323-3-1.pdf

and the accessories reaching the farmer's body.

\section{Results \\ Multi-criteria analysis of dermal exposure assessment models}

(Table 1) shows the description of the evaluated models according to the different criteria and characteristics of the model (i.e., origin, goal, basis, target group, availability, guidance, knowledge/equipment required, reliability, type of outcome, type of evaluated substance, dermal exposure pathway, dermal exposure descriptor, and evaluated body part). (Figure 1) shows the radar diagram with the multi-criteria analysis based on the defined criteria. From the analysis, it was found that DERM, DREAM, PHED and RISKOFDERM were the most appropriate models to be applied in farming systems in developing countries because they comply best with most of the criteria. However, there are still important criteria missing in the structure of each model. For instance, DERM has not been validated and it has been criticized about the reliability and reproducibility of the outcomes as there were mistakes in the methodology when the model was developed and tested in the same study area [20]. DREAM has been partially validated and it has been criticized about the accuracy of their estimations and the reproducibility in several case studies with different characteristics [39]. PHED is focused on farming systems in industrialized countries, its determinants evaluate the exposure during pesticide applications made by tractor and with motorized equipment, there is no distinction of the pesticide transport processes such as emission, transfer and deposition. RISKOFDERM is focused in SME's in industrialized countries but it does not differentiate the pesticide transportation processes like emission and transfer which are very important in farming systems with manual pesticide applications.

$\mathrm{COSHH}$ was excluded from the evaluation as it does not consider important criteria relevant for case studies in developing countries such as target group, as it is focused on SME's; guidance, as it is only available in a website with a user's manual for only some specific industries; outcome, as its assessment is qualitative; evaluated substances, as it does not evaluate pesticides in farming systems; dermal exposure descriptor, as it only assesses the potential exposure; and evaluated body parts, as it does make a distinction between any body part.

EASE was also excluded from the evaluation as it does not consider criteria such as target group, as it is focused on industrialized processes; guidance, as there is no a user's manual with the model description; outcome, as it is qualitative; dermal exposure descriptor, as it evaluates only the potential exposure; and evaluated body parts, as it takes only arms and forearms.

STOFENMANAGER was also excluded from the evaluation as it does not comply with criteria such as target group, as it is focused on industrial processes; guidance, as the website does not show the algorithms or model calculations; outcome, as the assessment is qualitative; and evaluated body parts, as there is no information available.

\section{Model outcomes for the case study of vereda la hoya}

(Table 3) shows the actual dermal exposure assessment outcomes for the case study performed by the selected models DERM, DREAM, PHED and RISKOFDERM and (Figure 2) shows the results of the sensitivity analysis of these models. The qualitative outcomes of actual dermal exposure for the four models differ significantly from each other. DERM assessed the actual dermal exposure as "moderate"; DREAM assessed the actual dermal exposure as "very high"; meanwhile both PHED and RISKOFDERM assessed the actual dermal exposure as "high". These assessments differ between each other because of the different structure of determinants within the models and the different scoring system for each determinant. According to the sensitivity analysis each model highlights different determinants which influence greatly the model outcomes. These determinants are spraying against the wind, height of the nozzle during the application, nozzle positioning in front and possible leaking of the sprayer for the model DERM; pesticide concentrations, emission, deposition and transfer for the model DREAM; washing the equipment, wearing gloves, replacement frequency of gloves and clothes, and personal hygiene for the model PHED; and the exposed body are and protection clothing for the model RISKOFDERM. In addition, the outcomes from DERM, DREAM, and PHED are semi-quantitative and the outcome from RISKOFDERM is quantitative. These issues show that the model outcomes are not comparable and an accurate risk assessment is only possible by measuring the dermal exposure directly in the study areas.

\section{Discussion \\ Evaluation of models}

Previous studies in Vereda La Hoya found that dermal exposure to pesticides is very high $[15,21]$ because of the inadequate work clothing, the modification of nozzles to increase the discharge, the inappropriate cleaning of the application equipment, the pesticide application against the wind direction and the use of pesticide with a high level of toxicity. Even though the evaluated dermal exposure models give an insight of the level of exposure, their outcomes are not comparable (Table 2). Furthermore, none of them covered all the relevant determinants according to the findings in previous studies. However, the model DREAM assesses the dermal exposure in the study area as "very high" and taking into account that its determinants cover many characteristics of these farming systems and the level of exposure risk in the study area, this model might give the most accurate dermal exposure estimation. Even though, the validity and accuracy have been partially proved [38,39], the results of this paper might help to the further validation of the model. 
Table 2. Description of the evaluated model for dermal exposure assessment according to the multi-criteria analysis.

\begin{tabular}{|c|c|c|c|c|c|c|c|}
\hline \multirow[t]{2}{*}{ CRITERIA } & \multicolumn{7}{|c|}{ Models } \\
\hline & COSHH & DERM & DREAM & EASE & PHED & RISKOF. & STOFFEN. \\
\hline Origin & UK & Nicaragua & The Netherlands & UK & USA/Canada & Europe & The Netherlands \\
\hline Year & 2002 & 2008 & 2003 & 1994 & 2002 & 2003 & 2003 \\
\hline Goal & $\begin{array}{l}\text { Risk assessment } \\
\text { in SMEs }\end{array}$ & $\begin{array}{l}\text { Risk assessment } \\
\text { in developing } \\
\text { countries }\end{array}$ & $\begin{array}{l}\text { Risk assessment } \\
\text { of occupational } \\
\text { exposure in any } \\
\text { situation }\end{array}$ & $\begin{array}{l}\text { Risk } \\
\text { assessment for } \\
\text { regulatory of } \\
\text { new chemicals }\end{array}$ & $\begin{array}{l}\text { Standardized } \\
\text { exposure estimates }\end{array}$ & $\begin{array}{l}\text { Risk assessment } \\
\text { for regulatory } \\
\text { and registration } \\
\text { processes }\end{array}$ & $\begin{array}{l}\text { Risk assessment in } \\
\text { SMEs }\end{array}$ \\
\hline Basis & $\begin{array}{l}\text { Operational } \\
\text { exposure levels } \\
\text { assess exposure } \\
\text { and R-phrases } \\
\text { for health } \\
\text { hazard }\end{array}$ & $\begin{array}{l}\text { Transport } \\
\text { Processes, } \\
\text { Schneider, } \\
\text { 1999[29] } \\
\text { DREAM, } 2003 \\
\text { [35] }\end{array}$ & $\begin{array}{l}\text { Transport pro- } \\
\text { cesses, Schnei- } \\
\text { der, 1999[29]. } \\
\text { Airborne } \\
\text { concentrations } \\
\text { (Cherrie, 1996) }\end{array}$ & $\begin{array}{l}\text { Computer } \\
\text { aided decision } \\
\text { tree format } \\
\text { (Johnston et al., } \\
\text { 2005), Schnei- } \\
\text { der, 1999[29] }\end{array}$ & $\begin{array}{l}\text { Reported } \\
\text { information on } \\
\text { pesticides and } \\
\text { monitoring data }\end{array}$ & $\begin{array}{l}\text { Schneider, } \\
\text { 1999[29]; } \\
\text { COSHH [16]. }\end{array}$ & $\begin{array}{l}\text { Schneider, 1999[29]; } \\
\text { COSHH [16]. Riskof- } \\
\text { derm[25] }\end{array}$ \\
\hline Target group & SME's & $\begin{array}{l}\text { Farmers in } \\
\text { developing } \\
\text { countries }\end{array}$ & $\begin{array}{l}\text { Industrial } \\
\text { processes and } \\
\text { farming systems }\end{array}$ & $\begin{array}{l}\text { Industrial } \\
\text { processes }\end{array}$ & $\begin{array}{l}\text { Regulatory agen- } \\
\text { cies, pesticide } \\
\text { industry }\end{array}$ & $\begin{array}{l}\text { Operational } \\
\text { and technical } \\
\text { staff mostly in } \\
\text { SMEs }\end{array}$ & Dutch companies \\
\hline Availability & $\begin{array}{l}\text { Electronic } \\
\text { version }\end{array}$ & Publication & Publication & $\begin{array}{l}\text { Software avail- } \\
\text { able }\end{array}$ & $\begin{array}{l}\text { Software and } \\
\text { publication }\end{array}$ & $\begin{array}{l}\text { Software and } \\
\text { publication }\end{array}$ & Website \\
\hline Guidance & $\begin{array}{l}\text { Website with } \\
\text { guidelines for } \\
\text { specific indus- } \\
\text { tries }\end{array}$ & Publication & Publication & Not available & Publication & Publication & $\begin{array}{l}\text { Website with no } \\
\text { guidelines about the } \\
\text { algorithms }\end{array}$ \\
\hline $\begin{array}{l}\text { Knowledge/ } \\
\text { Equipment } \\
\text { required }\end{array}$ & $\begin{array}{l}\text { No specific ex- } \\
\text { pertise required } \\
\text { and electronic } \\
\text { version avail- } \\
\text { able }\end{array}$ & $\begin{array}{l}\text { Basic math- } \\
\text { ematics skills } \\
\text { and easy to } \\
\text { carry out in the } \\
\text { field }\end{array}$ & $\begin{array}{l}\text { Basic mathemat- } \\
\text { ics skills and } \\
\text { easy to carry out } \\
\text { in the field }\end{array}$ & $\begin{array}{l}\text { Knowledge of } \\
\text { the model and } \\
\text { programming }\end{array}$ & $\begin{array}{l}\text { Knowledge of the } \\
\text { criteria and their } \\
\text { effects on expo- } \\
\text { sure. Computer } \\
\text { required }\end{array}$ & $\begin{array}{l}\text { Knowledge } \\
\text { of the model } \\
\text { and computer } \\
\text { required }\end{array}$ & $\begin{array}{l}\text { Internet access } \\
\text { required }\end{array}$ \\
\hline Reliability & $\begin{array}{l}\text { Evaluated by } \\
\text { the NIOSH } \\
\text { authority }\end{array}$ & Not validated & $\begin{array}{l}\text { Good inter-ob- } \\
\text { server agreement }\end{array}$ & $\begin{array}{l}\text { Distributed } \\
\text { over } 200 \text { users } \\
\text { in EU, USA, } \\
\text { ASIA and } \\
\text { Australia }\end{array}$ & $\begin{array}{l}\text { Evaluated and ap- } \\
\text { proved by EPA }\end{array}$ & $\begin{array}{l}\text { Developed by } \\
15 \text { European } \\
\text { institutes based } \\
\text { on a large } \\
\text { database. }\end{array}$ & $\begin{array}{l}\text { Widely used in The } \\
\text { Netherlands }\end{array}$ \\
\hline Outcome & $\begin{array}{l}\text { Semi-quantita- } \\
\text { tive (bands) }\end{array}$ & $\begin{array}{l}\text { Semi-quanti- } \\
\text { tative }\end{array}$ & $\begin{array}{l}\text { Semi-quanti- } \\
\text { tative }\end{array}$ & $\begin{array}{l}\text { Quantifies } \\
\text { the degree of } \\
\text { exposure }\end{array}$ & Semi-quantitative & Quantitative & $\begin{array}{l}\text { Ranking of risks in } \\
\text { bands }\end{array}$ \\
\hline $\begin{array}{l}\text { Type of } \\
\text { evaluated } \\
\text { substances }\end{array}$ & $\begin{array}{l}\text { Chemical } \\
\text { products except } \\
\text { pesticides }\end{array}$ & Pesticides & $\begin{array}{l}\text { Metals, fluids } \\
\text { and pesticides }\end{array}$ & $\begin{array}{l}\text { Pure substanc- } \\
\text { es, no mixtures }\end{array}$ & Pesticides & $\begin{array}{l}\text { Pure substances } \\
\text { including } \\
\text { pesticides }\end{array}$ & $\begin{array}{l}\text { Pure substances and } \\
\text { mixtures }\end{array}$ \\
\hline $\begin{array}{l}\text { Evaluated } \\
\text { dermal } \\
\text { exposure } \\
\text { pathway }\end{array}$ & $\begin{array}{l}\text { Deposition, } \\
\text { indirect and } \\
\text { direct contact }\end{array}$ & $\begin{array}{l}\text { Transfer, } \\
\text { deposition and } \\
\text { emission }\end{array}$ & $\begin{array}{l}\text { Transfer, } \\
\text { deposition and } \\
\text { emission }\end{array}$ & $\begin{array}{l}\text { Emission to } \\
\text { surface, air, } \\
\text { outer clothing } \\
\text { layers and } \\
\text { direct to skin }\end{array}$ & No Data & $\begin{array}{l}\text { Deposition and } \\
\text { direct contact }\end{array}$ & $\begin{array}{l}\text { Inhalation Exposure } \\
\text { (near and far field). } \\
\text { Total dermal exposure }\end{array}$ \\
\hline $\begin{array}{l}\text { Dermal } \\
\text { exposure } \\
\text { descriptor }\end{array}$ & $\begin{array}{l}\text { Potential } \\
\text { exposure }\end{array}$ & $\begin{array}{l}\text { Potential and } \\
\text { actual exposure }\end{array}$ & $\begin{array}{l}\text { Potential and } \\
\text { actual exposure }\end{array}$ & $\begin{array}{l}\text { Potential } \\
\text { exposure }\end{array}$ & Actual exposure & $\begin{array}{l}\text { Potential and } \\
\text { actual exposure }\end{array}$ & $\begin{array}{l}\text { Potential and actual } \\
\text { exposure }\end{array}$ \\
\hline $\begin{array}{l}\text { Evaluated } \\
\text { Body Parts }\end{array}$ & $\begin{array}{l}\text { No information } \\
\text { available }\end{array}$ & $\begin{array}{l}\text { Front and back } \\
\text { side of neck, } \\
\text { thorax, arms, } \\
\text { forearms, } \\
\text { hands, thighs, } \\
\text { legs, feet, fore- } \\
\text { head and left } \\
\text { and right side } \\
\text { of face }\end{array}$ & $\begin{array}{l}\text { Head, upper } \\
\text { and lower arms, } \\
\text { hands, front } \\
\text { torso, back, up- } \\
\text { per legs, lower } \\
\text { legs and feet }\end{array}$ & $\begin{array}{l}\text { Hands and } \\
\text { forearms }\end{array}$ & $\begin{array}{l}\text { Head, face, back } \\
\text { and front neck, } \\
\text { chest/stomach, } \\
\text { back, upper arms, } \\
\text { forearms, hands, } \\
\text { thighs, lower legs, } \\
\text { feet. }\end{array}$ & $\begin{array}{l}\text { Hands, arms, } \\
\text { head, front and } \\
\text { back side of } \\
\text { legs, front and } \\
\text { back of torso }\end{array}$ & $\begin{array}{l}\text { No information } \\
\text { available }\end{array}$ \\
\hline Reference & [16] & {$[3]$} & {$[38]$} & {$[5]$} & {$[8]$} & {$[25]$} & {$[32]$} \\
\hline
\end{tabular}


Lesmes Fabian et al. Journal of Environmental Engineering \& Ecological Science 2013, http://www.hoajonline.com/journals/pdf/2050-1323-3-1.pdf

Table 3. Actual Dermal Exposure Assessments by the Selected Models for the Case Study of Vereda La Hoya.

\begin{tabular}{llllll}
\hline Model & Case Study Score & \multicolumn{2}{c}{ Model Scoring Ranges } & Unit & Qualitative Assessment \\
\hline \multicolumn{5}{c}{ Lowes Value } & Highes Value \\
\hline DERM & 44.28 & 0 & $>150$ & Unitless & Moderate \\
DREAM & 359.0 & 0 & $>1000$ & Unitless & Very High \\
PHED & 15.2 & 0.05 & $>30$ & Unitless & High \\
RISKOFDERM & 0.65 & 0 & $>30$ & $\mathrm{mg} / \mathrm{cm}^{2} / \mathrm{h}$ & High \\
\hline
\end{tabular}

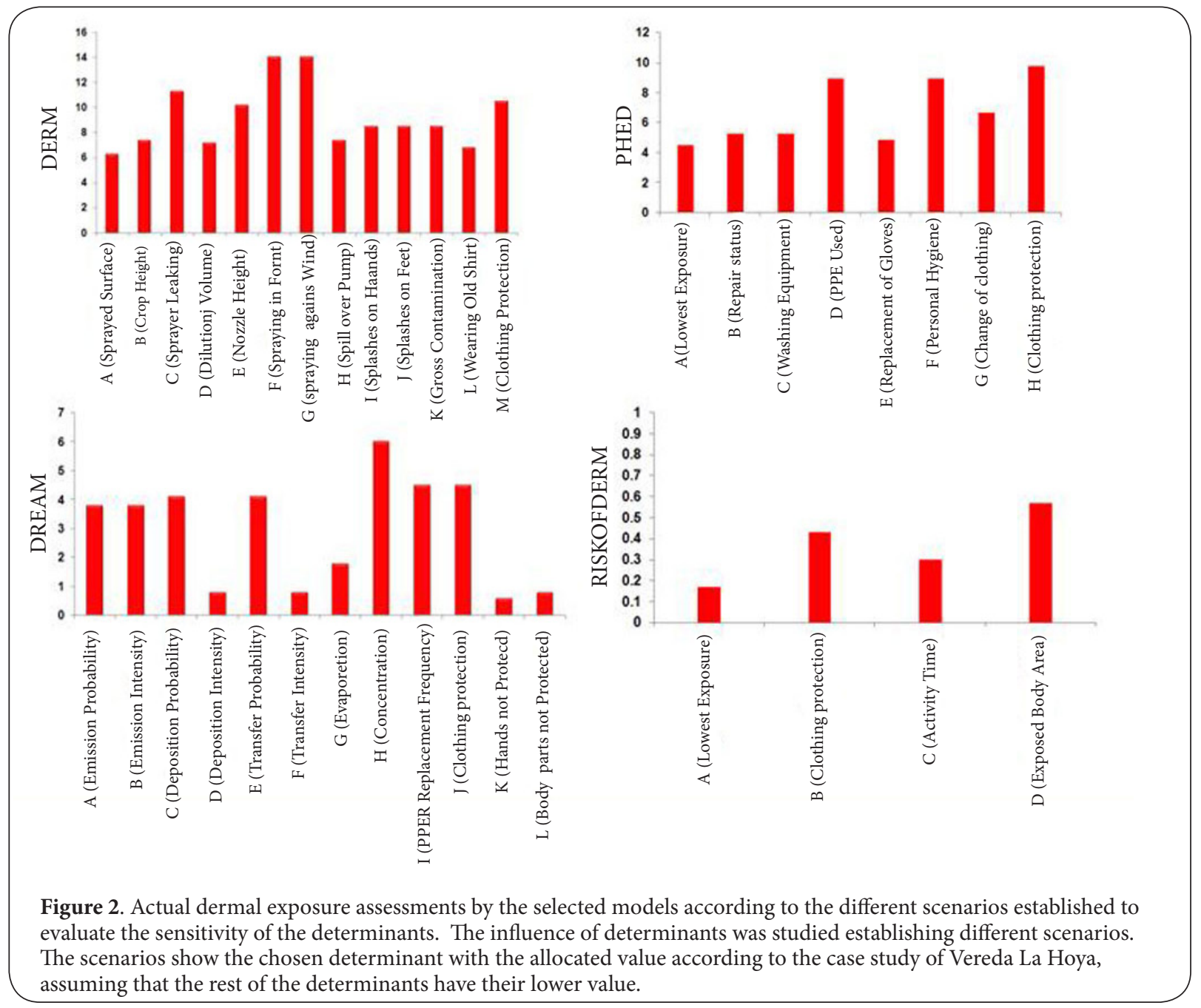

Based on the sensitivity analysis and the results, several issues might be taken into account inside the structure of the models, which could improve the accuracy of the estimations. These issues are discussed separately for each model.

\section{DERM (Dermal exposure ranking method)}

This is a low-cost and easy-to-use method for the assessment of exposure to pesticides in developing countries and it helps to identify the most determinants that influence the exposure; however, the validation of this model is incomplete and important determinants like washing the equipment, task duration, wearing gloves, frequency of replacement of gloves, work clothing, personal hygiene and climate conditions like wind speed and humidity, should be included to improve the assessment.

\section{DREAM (Dermal exposure assessment method)}

This model approach has a structure in which the determinants cover most of the characteristics present in the case study. However, there are still some important determinants that 
Lesmes Fabian et al. Journal of Environmental Engineering \& Ecological Science 2013,

can improve the accuracy. One is the differentiation of the level of protection for the body parts. Previous studies have found that the level of protection given by the work clothing differs between each body part [21] and the model only differentiates the protection for the body and the hands. On the other hand, the inclusion of climate conditions like wind speed and humidity which influence the dermal exposure, might improve the model accuracy as well. Despite this issue and comparing the model outcome with the exposure assessment previously made in the study area, the qualitative assessment of this model is the most realistic from the four evaluated models.

\section{PHED (Pesticide handlers exposure database)}

This method is easy to use and includes determinants not included in other models, such as washing the equipment, wearing gloves, replacement frequency of gloves and clothes, and personal hygiene, which, according to the sensitivity analysis, influence strongly the scoring. However, other determinants in the model like using enclosed mixing system, tractor with enclosed cab and application with motorized sprayers, are not relevant for the working situations of farming systems in developing countries. Additionally, this model does not assess processes like emission and transfer; therefore, this model is useful for a quick assessment of dermal exposure in agricultural systems in industrialized countries but it is not appropriate for study areas in developing countries.

\section{RISKOFDERM (Risk assessment of occupational dermal exposure to chemicals)}

This model assesses easily the dermal exposure, giving estimations in terms of $\mathrm{mg} / \mathrm{cm}^{2} / \mathrm{h}$ which facilitates the comparison with direct dermal exposure measurements or reference values to assess the risk. However, this assessment does not take into account emission and transfer processes and also includes determinants only relevant for agricultural systems in industrialized countries such as automation. Therefore, this model is not appropriate for the case study of farming systems in developing countries.

DERM, DREAM, PHED and RISKOFDERM were applied in the case study of Vereda La Hoya in which pesticide management is performed by handed-pressurized sprayers. From the comparison of the models, DERM and DREAM were found to be the most appropriate models. These results are valid for potato farming systems and many other crop systems with similar characteristics in different regions in Latin America and might be also be valid for other regions worldwide with similar pesticide applications in Africa or Asia. However, the results are not valid for other sophisticated pesticide applications in crops in developing countries such as flowers, banana, coffee, sugar cane, rice, etc. For these crops, the comparison of model outcomes might give a different conclusion. For instance, DREAM and PHED are models whose assessments are able to be targeted on pesticide applications with sophisticated techniques and they might be useful for the exposure assessment in these farming systems.

Improvement in the structure of the determinants of the models DREAM and DERM might not only improve the accuracy of exposure estimations but also might result in a brand new model for human exposure with high specificity for farming systems in developing countries.

\section{Conclusions}

This research evaluated in depth the available models for human exposure assessment, so assessors can decide which model is the most appropriate according to the characteristics of the study area in which the model is going to be applied and furthermore this research suggested improvements in the models in order to increase the estimation accuracy.

From a comparison of the models after a multi-criteria analysis, DERM, DREAM, PHED and RISKOFDERM were selected as the most appropriate models as they fulfill the required criteria for the case studies in developing countries. Afterwards, these four models were applied to assess the dermal exposure in the case study of Vereda La Hoya and their determinants were compared with the characteristics of the study area. DREAM and DERM were found as the most appropriate models. However, because some relevant determinants are still absent (i.e., differentiation in the protection factor according to the different body parts and climate conditions in the case of DREAM, and washing the equipment, task duration, wearing gloves, frequency and replacement of gloves, work clothing, personal hygiene and climate conditions in the case of DERM), the accuracy of these models could be improved if these determinants are included. When comparing the final model assessment of dermal exposure in the study area, DREAM was found as the model that assesses more accurately the dermal exposure in this study area.

\section{Competing interests}

The authors declare that they have no competing interests.

Authors' contributions

\begin{tabular}{|l|c|c|c|}
\hline Authors' contributions & CLF & ST & CRB \\
\hline Research concept and design & $\checkmark$ & -- & -- \\
\hline Collection and/or assembly of data & $\checkmark$ & $\checkmark$ & $\checkmark$ \\
\hline Data analysis and interpretation & $\checkmark$ & $\checkmark$ & $\checkmark$ \\
\hline Writing the article & $\checkmark$ & -- & $\checkmark$ \\
\hline Critical revision of the article & -- & -- & $\checkmark$ \\
\hline Final approval of article & -- & -- & $\checkmark$ \\
\hline Statistical analysis & $\checkmark$ & $\checkmark$ & $\checkmark$ \\
\hline
\end{tabular}

\section{Acknowledgement}

This research was funded by the Swiss Science National Foundation.

\section{Publication history}

Editor: Mustafa S. Yazgan, Istanbul Technical University, Turkey. Senior Editor: Yehia Khalil, Yale School of Forestry \& Environmental 
Studies, USA.

EIC: Rob Harrison, University of Washington, USA.

Received: 08-Oct-2013 Revised: 28-Nov-2013

Accepted:09-Dec-2013 Published: 20-Jan-2014

\section{References}

1. Auffarth J, Van Hemmen J.J, Hebisch R, Lechtenberg-Auffarth E, Marquart J, Oppl R, Rajan B and Wriedt H. The RISKOFDERM project. RISKOFDERM - Europas beschäftigte sollen nicht länger ihre haut zu markte tragen. 2003; 63:399-405. I Pdf

2. Blanco LE, Aragon A, Lundberg I, Liden C, Wesseling C and Nise G. Determinants of dermal exposure among Nicaraguan subsistence farmers during pesticide applications with backpack sprayers. Ann Occup Hyg. 2005; 49:17-24. I Article I PubMed

3. Blanco LE, Aragon A, Lundberg I, Wesseling C and Nise G. The determinants of dermal exposure ranking method (DERM): a pesticide exposure assessment approach for developing countries. Ann Occup Hyg. 2008; 52:535-44. I Article I PubMed

4. Cherrie J.W and Schneider T. Validation of a New Method for Structured Subjective Assessment of Past Concentrations. Ann Occup Hyg. 1999; 43:235-245. I Article

5. Cherrie J.W, Tickner J and Friar J. Evaluation and further development of the EASE model 2.0. HSE Books., Sudbury, UK. 2003.

6. Creely KS, Tickner J, Soutar AJ, Hughson GW, Pryde DE, Warren ND, Rae R, Money C, Phillips A and Cherrie JW. Evaluation and further development of EASE model 2.0. Ann Occup Hyg. 2005; 49:135-45. | Article I PubMed

7. Czitrom V. One-Factor-at-a-Time versus Designed Experiments. The American Statistician. 1999; 53:126-131. I Article

8. Dosemeci M, Alavanja MC, Rowland AS, Mage D, Zahm SH, Rothman N, Lubin JH, Hoppin JA, Sandler DP and Blair A. A quantitative approach for estimating exposure to pesticides in the Agricultural Health Study. Ann Occup Hyg. 2002; 46:245-60. I Article I PubMed

9. FAO. International Code of Conduct on the Distribution and Use of Pesticides: Guidance on Pest and Pesticide Management Policy Development. Food and Agriculture Organization of the United Nations. Rome. 2010. I Pdf

10. FAO, WFP and IFAD. The State of Food Insecurity in the World 2012. Food and Agriculture Organization of the United Nations. Rome, Italy. 2012. I Pdf

11. Fenske RA. Dermal exposure: a decade of real progress. Ann Occup Hyg. 2000; 44:489-91. I Article I PubMed

12. Feola $\mathrm{G}$ and Binder C.R.Identifying and investigating pesticide application types to promote a more sustainable pesticide use. The case of smallholders in Boyacá, Colombia. Crop Protection. 2010; 29:612-622. | Article

13. Feola $G$ and Binder CR. Why don't pesticide applicators protect themselves? Exploring the use of personal protective equipment among Colombian smallholders. Int J Occup Environ Health. 2010; 16:1123. I Article I PubMed

14. Fernandez A, Tobon J, Caicedo L, Cardenas J and Senior A. Mis Buenas Practicas Agricolas. Ministerio de Agricultura y Desarrollo Rural, Insituto Colombiano Agropecuario, Corporacion Colombia Internacional. Yerimpresos, Bogota, Colombia. 2009. | Pdf

15. Garcia-Santos G, Scheiben D and Binder CR. The weight method: a new screening method for estimating pesticide deposition from knapsack sprayers in developing countries. Chemosphere. 2011; 82:1571-7. | Article I PubMed

16. Garrod AN and Rajan-Sithamparanadarajah R. Developing COSHH Essentials: dermal exposure, personal protective equipment and first aid. Ann Occup Hyg. 2003; 47:577-88. I Article I PubMed

17. Hughes EA, Zalts A, Ojeda JJ, Flores AP, Glass RC and Montserrat JM. Analytical method for assessing potential dermal exposure to captan, using whole body dosimetry, in small vegetable production units in
Argentina. Pest Manag Sci. 2006; 62:811-8. | Article I PubMed

18. Juraske R, Vivas CS, Velasquez AE, Santos GG, Moreno MB, Gomez JD, Binder $C R$, Hellweg $S$ and Dallos JA. Pesticide uptake in potatoes: model and field experiments. Environ Sci Technol. 2011; 45:651-7. | Article | PubMed

19. Krieger RI. Pesticide exposure assessment. Toxicol Lett. 1995; 82-83:6572. | Article | PubMed

20. Kromhout $H$, Van Wendel De Joode B and Van Hemmen J. The accuracy of DERM may be a self-fulfilling DREAM. Ann Occup Hyg. 2008; 52:7834. | Article | PubMed

21. Lesmes-Fabian C, Garcia-Santos G, Leuenberger F, Nuyttens D and Binder CR. Dermal exposure assessment of pesticide use: the case of sprayers in potato farms in the Colombian highlands. Sci Total Environ. 2012; 430:202-8. I Article I PubMed

22. M.A.D.R. Oferta Agropecuaria. In: Encuesta Nacional Agropecuaria Cifras 2009 (Ed.). Corporación Colombia Internacional, Ministerio de Agricultura y Desarrollo Rural, Bogotá, Colombia. 2009.

23. Marquart H, Heussen H, Le Feber M, Noy D, Tielemans E, Schinkel J, West $J$ and Van Der Schaaf D. 'Stoffenmanager', a web-based control banding tool using an exposure process model. Ann Occup Hyg. 2008; 52:429-41. | Article | PubMed

24. Murphy JM, Sexton DM, Barnett DN, Jones GS, Webb MJ, Collins M and Stainforth DA. Quantification of modelling uncertainties in a large ensemble of climate change simulations. Nature. 2004; 430:768-72. I Article I PubMed

25. Oppl R, Kalberlah F, Evans PG and van Hemmen JJ. A toolkit for dermal risk assessment and management: an overview. Ann Occup Hyg. 2003; 47:629-40. I Article I PubMed

26. Pimentel D. Pesticides and Pest Control., Integrated Pest Management: Innovation Development Process (Vol. 1). Springer. 2009; 83-87.

27. Poats S.V and Crissman C. Pobreza Rural y Deterioro Ambiental en el Area de Uso de Agua del Rio El Angel, Carchi, Ecuador. Definicion del Problema de Caso y Nota Conceptual para el primer tallo de Fontagro 1999. FLACSO FUNDAGRO. Centro International de la Papa. Ecuador. 1999. I Pdf

28. Schneider T, Cherrie JW, Vermeulen R and Kromhout H. Dermal exposure assessment. Ann Occup Hyg. 2000; 44:493-9. I Article I PubMed

29. Schneider T, Vermeulen R, Brouwer DH, Cherrie JW, Kromhout $\mathrm{H}$ and Fogh CL. Conceptual model for assessment of dermal exposure. Occup Environ Med. 1999; 56:765-73. I Article I PubMed Abstract | PubMed Full Text

30. Schöll R and Binder C.R. Comparison of farmers' mental models of the present and the future: A case study of pesticide use. Futures. 2010; 42:593-603. | Article

31. Schütz L. Survey of Agricultural Practices and Possibilities for Integrated Pest Management and Sustainable Resource Management in the Mojanda Watershed, Ecuador. Master Thesis. Faculty of Agricultural Sciences. Georg-August University of Göttingen, Germany. 2012.

32. Tielemans E, Noy D, Schinkel J, Heussen H, Van Der Schaaf D, West J and Fransman W. Stoffenmanager exposure model: development of a quantitative algorithm. Ann Occup Hyg. 2008; 52:443-54. | Article | PubMed

33. Tielemans E, Schneider T, Goede H, Tischer M, Warren N, Kromhout $H$, Van Tongeren M, Van Hemmen J and Cherrie JW. Conceptual model for assessment of inhalation exposure: defining modifying factors. Ann Occup Hyg. 2008; 52:577-86. I Article I PubMed

34. U.S.EPA. Dermal exposure assessment: A summary of EPA Approaches. U.S. Environmental Protection Agency, Washington, DC, EPA/600/R07/040F. 2007.

35. Van-Wendel-de-Joode B, Brouwer DH, Vermeulen R, Van Hemmen JJ, Heederik D and Kromhout H. DREAM: a method for semi-quantitative dermal exposure assessment. Ann Occup Hyg. 2003; 47:71-87. I Article I PubMed

36. van Hemmen JJ. EUROPOEM, a predictive occupational exposure database for registration purposes of pesticides. Appl Occup Environ Hyg. 2001; 16:246-50. I Article I PubMed 
Lesmes Fabian et al. Journal of Environmental Engineering \& Ecological Science 2013, http://www.hoajonline.com/journals/pdf/2050-1323-3-1.pdf

37. van Hemmen JJ, Auffarth J, Evans PG, Rajan-Sithamparanadarajah B, Marquart $\mathrm{H}$ and Oppl R. RISKOFDERM: risk assessment of occupational dermal exposure to chemicals. An introduction to a series of papers on the development of a toolkit. Ann Occup Hyg. 2003; 47:595-8. | Article I PubMed

38. van Wendel de Joode B, van Hemmen JJ, Meijster T, Major V, London L and Kromhout $\mathrm{H}$. Reliability of a semi-quantitative method for dermal exposure assessment (DREAM). J Expo Anal Environ Epidemiol. 2005; 15:111-20. | Article | PubMed

39. van Wendel de Joode B, Vermeulen R, van Hemmen JJ, Fransman W and Kromhout H. Accuracy of a semiquantitative method for Dermal Exposure Assessment (DREAM). Occup Environ Med. 2005; 62:623-32. | Article | PubMed Abstract | PubMed Full Text

40. Zhang W, Jiang F and Ou J. Global Pesticide Consumption and Pollution: with China as a Focus. Proceedings of the International Academy of Ecology and Environmental Sciences 1. 2011. | Pdf

\section{Citation:}

Lesmes Fabian C, Teubl S and Binder CR. Evaluation of models for dermal exposure assessment in farming systems in developing countries. J Environ Eng Ecol Sci. 2014; 3:1. http://dx.doi.org/10.7243/2050-1323-3-1 